\title{
PENDAMPINGAN PENYUSUNAN LAPORAN KEUANGAN USAHA RINTISAN KEUANGAN DIGITAL TEKNOLOGI ASURANSI SYARIAH YUKTAKAFUL (INSURTECH)
}

\author{
Dhona Shahreza1), Lindiawatie ${ }^{1)}$ \\ 1)Program Studi Pendidikan Ekonomi, Fakultas Ilmu Pendidikan dan Pengetahuan Sosial, Universitas Indraprasta \\ PGRI, Jakarta Selatan, DKI Jakarta, Indonesia \\ Corresponding author: Dhona Shahreza \\ E-mail: dhona.shahreza@gmail.com
}

Diterima 14 Oktober 2021, Disetujui 27 November 2021

\begin{abstract}
ABSTRAK
Peningkatan pengguna internet sekarang ini berdampak pada berkembangnya usaha rintisan (startup) layanan digital yang membuat bisnis ini cukup menjanjikan. Yuktakaful sebagai salah satu startup penyedia layanan platform fintech di bidang keuangan khususnya asuransi terus berkembang menjadi organisasi yang menyediakan portal layanan digital asuransi (insurtech) berbasis web dan aplikasi mobile dengan berpegang pada prinsip Syariah. Namun, sebagai usaha yang baru berdiri tahun 2019 Yuktakaful memiliki kendala dalam menyusun laporan keuangan yang baik yang sesuai dengan format OJK. Padahal penyusunan laopran keuangan yang tidak memadai akan menghasilkan laporan keuangan yang tidak akurat. Kegiatan abdimas ini bertujuan untuk memberikan pendampingan kepada Yuktakaful dalam menyusun laporan keuangan yang sesuai dengan format OJK dan mengatasi persoalan keuangan yang terjadi saat ini. Berdasarkan hasil bimbingan dan evaluasi yang telah dilakukan maka kegiatan abdimas pendampingan dalam penyusunan laporan keuangan pada usaha rintisan inovasi keuangan digital ini sangat membawa manfaat yang besar bagi mitra. Mitra mengalami peningkatan tidak hanya dari segi pengetahuan dan pemahaman dalam penyusunan laporan keuangan saja tetapi juga muncul kepercayaan diri menghadapi regulator dan investor.
\end{abstract}

Kata kunci: startup; insurtech; YukTakaful; laporan keuangan

\begin{abstract}
The current increase in internet users impacts on the increasing of startups digital service that make this business quite promising. Yuktakaful as one of the startups providing financial technology platform services in the financial sector, especially insurance, continues to develop into an organization that provides web-based insurance digital service portals (insurtech) and mobile applications by adhering to Sharia principles. However, as a business that was just established in 2019, Yuktakaful had problems in compiling good financial reports that suitable with the OJK format. In fact, preparing inadequate financial reports will result in inaccurate financial statements. This abdimas activity aims to provide assistance to Yuktakaful in compiling financial reports in accordance with the OJK format and overcoming current financial problems. Based on the results of the guidance and evaluation that have been carried out, the activities of abdimas mentoring in the preparation of financial reports for this digital financial innovation startup have brought great benefits to partners. Partners have increased not only in terms of knowledge and understanding in the preparation of financial statements but also confidence in facing regulators and investors.
\end{abstract}

Keywords: startup; insurtech; YukTakaful; financial reports

\section{PENDAHULUAN}

Usaha rintisan atau dikenal Startup merupakan suatu bisnis yang baru berdiri dan berkembang melalui dukungan layanan digital yang masih memerlukan pendanaan untuk beroperasi dengan kelompok kerja yang minimalis. Secara bahasa, startup berasal dari bahasa Inggris, Saat ini, banyak bermunculan pengusaha muda dengan usaha startup yang penuh inovasi dan kreativitas tanpa batas (liputan6.com, 2019). Sekarang ini sudah ada ribuan usaha startup lokal berdiri di Indonesia. Ini karena potensi pengguna internet yang semakin meningkat sehingga bisnis ini cukup menjanjikan untuk berdiri di Indonesia (kompas.com, 2020) dengan karakteristik antara lain: usaha perusahaan kurang dari 3 tahun, jumlah karyawan yang masih terbatas dan keahlian karyawannya yang multitasking, semangat yang menggebu, bergerak di bidang 
teknologi, menjadikan web sebagai sarana utama dan konsumen sebagai prioritas utama (liputan6.com, 2019).

Berbagai bentuk layanan keuangan yang berbasis teknologi informasi yang ditawarkan oleh lembaga keuangan, baik yang dalam pengawasan OJK seperti layanan pada bank, asuransi atau lembaga keuangan terdaftar lainnya maupun usaha rintisan yang belum terdaftar dan di bawah pengawasan OJK. Keadaan ini diharapkan dapat dimanfaatkan oleh fintech untuk mengambil peranan sebagai pendukung dalam meningkatkan tingkat inklusi keuangan di Indonesia (Njatrijani, 2019).

Sebagai salah satu usaha startup yang bergerak di bidang teknologi informasi, Yuktakaful didirikan pada tahun 2019 dan terus berkembang menjadi organisasi yang menyediakan layanan platform fintech di bidang keuangan khususnya asuransi. YukTakaful menyediakan portal layanan digital asuransi (insurtech) berbasis web dan aplikasi mobile dengan berpegang pada prinsip Syariah untuk memberikan kemudahan kepada nasabah, dimulai dari layanan pembelian polis hingga penyelesaian klaim.

Setiap perusahaan berkewajiban mengelola keuangan dan mampu menghasilkan laporan keuangan sebagai hasil kinerja keuangan pada setiap periode akuntansi. Pembukuan pada dasarnya pencatatan semua informasi mengenai transaksi dan kegiatan keuangan dari pebisnis tentang proses akuntansi mereka (Wahyuningsih, Setiawati, \& Prasojo, 2017). Pencatatan laporan keuangan yang sistematis bermanfaat dalam memberikan informasi kas yang dapat dipercaya mengenai posisi keuangan perusahaan, memberikan informasi keuangan tentang hasil usaha, memberikan informasi yang berguna dalam pengambilan keputusan serta informasi penting lainnya yang relevan terhadap pihak yang berkepentingan (Rivai, Basir, Sudarto, \& Veithzal, 2013). Pihak yang berkepentingan meliputi pihak internal perusahaan, maupun eksternal perusahaan seperti kreditor maupun investor. Selain itu, pelaporan keuangan juga merupakan bentuk pertanggungjawaban manajemen dalam mengelola sumber daya yang dimiliki perusahaan (Wahyuningsih, Setiawati, \& Prasojo, 2017).

Oleh sebab itu, diperlukan laporan keuangan yang berkualitas, yaitu yang memenuhi standar, seperti: dapat dipahami oleh pengguna, relevan dengan kebutuhan pengguna khususnya dalam pengambilan keputusan, materialitas, dapat diandalkan, transaksi dan kondisi dicatat dan disajikan dengan substansi san realitas ekonomi, memegang prinsip kehati-hatian dalam memberi pertimbangan, kelengkapan, dapat dibandingkan, tepat waktu terciptanya keseimbangan antara biaya dan manfaat (Rudianto, 2012, pp. 21-22)

Selain itu, laporan keuangan dibuat agar dapat menarik minat investor untuk menanamkan modalnya. Ini karena laporan keuangan berperan sebagai tolak ukur jenis investasi yang akan diberikan, menjadikan laporan keuangan sebagai bahan proyeksi investasi, sebagai media dalam mengembangkan relasi dengan tujuan untuk mendapatkan perhatian publik, menghindari kerugian massal (hanindo.co.id, 2020)

Pengelolaan keuangan yang kurang memadai akan berdampak terhadap laporan keuangan yang dihasilkan karena informasi keuangan yang dihasilkan menjadi tidak akurat. Ersa Tri Wahyuni menegaskan bahwa rata-rata perusahaan digital memiliki masalah dalam menyusun laporan keuangan (republika.co.id, 2019). Bahkan, menurut laporan Indonesia Digital Creative Industry Society berjudul Mapping \& Database Startup Indonesia 2018, terdapat beberapa masalah yang kerap dihadapi usaha stratup di Indonesia, yaitu: penyusunan laporan keuangan yang masih berantakan, keterlambatan pembayaran, modal kerja yang terbatas dan proyeksi keuangan yang tidak teratur (paper.id, 2020). Keadaan ini yang sedang dihadapi oleh YukTakaful. Sebagai usaha startupTyang baru berdiri setahun belakangan, Yuktakaful harus mampu menghasilkan Laporan Keuangan sesuai dengan format yang telah ditentukan oleh OJK. Sementara kemampuan yang dimiliki oleh karyawannya masih terbatas.

Berdasarkan kenyataan tersebut, maka kegiatan pengabdian masyarakat mencoba untuk memberikan solusi dalam mengatasi permasalahan pelaporan laporan keuangan. Kegiatan abdimas ini bertujuan untuk memberikan pendampingan YukTakaful dalam menyusun laporan keuangan yang sesuai dengan format OJK dan mengatasi persoalan keuangan yang terjadi saat ini. Manfaat abdimas ini sebagai bentuk kontribusi bagi usaha startup dalam menyusun laporan keuangan yang baik dan tepat sehingga memudahkan YukTakaful dalam mendapatkan modal dan mengukuhkan eksistensinya di bidang digital keuangan

\section{METODE}

Kegiatan Pengabdian Masyarakat dilaksanakan pada tanggal 25 Agustus 2020 saat pandemi masih melanda, bertempat di kantor YukTakaful dengan alamat Griya Depok 
Asri, Depok Jawa Barat dengan peserta yang hadir sebanyak 2 orang sedangkan tim Pengabdian Masyarakat sebanyak 2 orang.

\section{Teknik Pelaksanaan}

Secara umum teknis pelaksanaan Pengabdian Masyarakat dibagi menjadi 3 bagian, yaitu (Gambar 1):

1. Kegiatan pra abdimas : Kegiatan ini diawali dengan menggali informasi dari mitra tentang permasalahan dalam penyusunan laporan keuangan berdasarkan wawancara singkat. Pemasalahan kemudian disusun secara sistematis dan melakukan studi Pustaka sebagai perbandingan dengan teori yang ada.

2. Kegiatan saat abdimas: Pelaksanaan abdimas berlangsung selama satu hari dengan rincian sebagai berikut:

a. Penyampaian Materi (09.00 12.00). Sesi ini dimulai pukul 09.00 WIB sampai 12.00 WIB. Sesi penyampaian materi diisi dengan pembekalan pengetahuan tentang laporan keuangan; jenis, akun dan dokumen yang perlu disiapkan serta permasalahan yang sering terjadi dalam menyusun laporan keuangan.

b. Sesi diskusi (13.00 - 17.00). Sesi ini dimulai setelah tim dan mitra beristirahat selam satu jam. Pada sesi ini, setelah informasi mengenai jenis laporan keuangan, akun serta dokumen apa saja yang perlu disiapkan, maka mitra mulai menyusun laporan keuangan yang sesuai dengan format OJK di bawah bimbingan tim abdimas. Laporan Keuangan yang perlu disiapkan berupa Laporan Laba Rugi dan Neraca.

3. Kegiatan pasca abdimas: tim abdimas melakukan bimbingan dan menyediakan waktu konsultasi bagi mitra setelah pendampingan pembuatan laporan dilakukan.

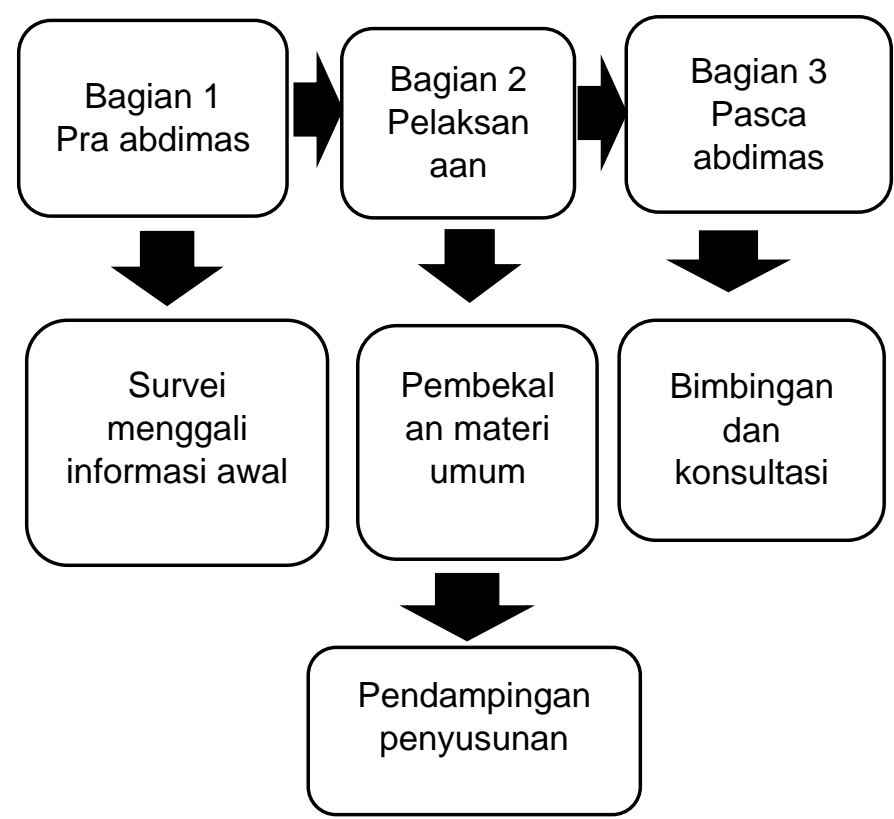

Gambar 1.Tiga Bagian Pelaksanaan Abdimas

\section{HASIL DAN PEMBAHASAN}

Pengabdian masyarakat ini dilaksanakakan secara empat tahap, yaitu (Gambar 4):

\section{1) Tahap Pembekalan}

Pada tahap ini tim abdimas menyampaikan materi umum dasar-dasar dan tujuan penyusunan laporan keuangan (Gambar 2). Laporan keuangan merupakan laporan yang menunjukkan kondisi perusahaan saat ini yang bertujuan (Kasmir, 2017, pp. 23-24):

1. Memberikan informasi tentang jenis dan jumlah aktiva, kewajiban, modal, pendapatan dan biaya

2. Memberikan informasi tentang perubahan-perubahan yang terjadi terhadap aset, liabilitas dan ekuitas

3. Memberikan informasi tentang kinerha manajemen dalam suatu periode.

Berdasarkan tujuan di atas, maka sasaran utama dalam pelaporan keuangan adalah untuk kepentingan pemilik dan manajemen perusahaan serta pihak internal lainnya di perusahaan maupun pihak eksternal, seperti kreditor, pemerintah dan investor (Kasmir, 2017, pp. 18-22).

Jenis laporan keuangan yang lazim dibuat pada akhir periode akuntansi antara lain (Rudianto, 2012, pp. 17-20):

1. Laporan Laba Rugi, yaitu Laporan yang menunjukkan kemampuan perusahaan dalam menghasilkan laba selama satu periode. Laporan ini terdiri atas pendapatan dan beban yang akan menghasilkan laba/rugi. 
2. Laporan perubahan ekuitas merupakan laporan yang menunjukkan perubahan ekuitas pemilik selama satu periode

3. Neraca merupakan laporan yang menjelaskan posisi aset, liabilitas dan ekuitas perusahaan pada tanggal tertentu.

4. Laporan arus kas merupakan laporan keluar masuk kas selama satu periode beserta sumbernya. Laporan arus kas menggambarkan tiga aktivitas, yaitu aktivitas operasi, investasi dan pembiayaan

5. Catatan atas laporan keuangan. Merupakan informasi tambahan terkait hal-hal yang berhubungan langsung dengan laporan keuangan yang disajikan dalam periode tertentu.

6. Laporan posisi keuangan pada awal periode komparatif

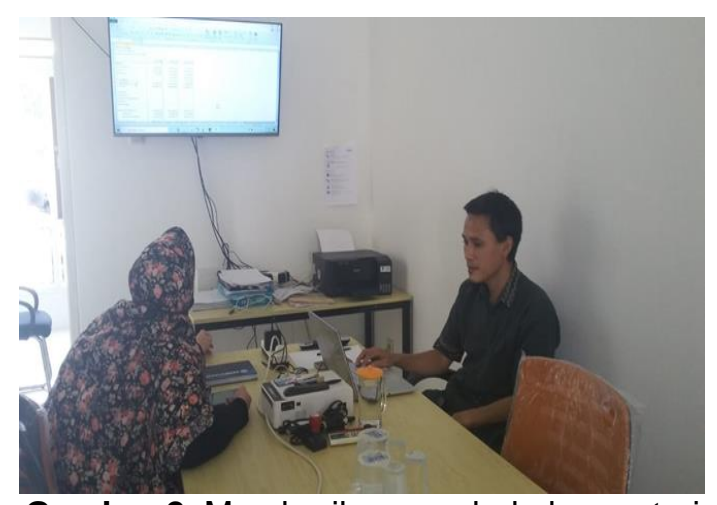

Gambar 2. Memberikan pembekalan materi menyusun laporan keuangan

\section{2) Tahap Pendampingan Penyusunan Laporan Keuangan Sesuai Format OJK}

Sesi selanjutnya adalah pendampingan yang diisi dengan mendampingi mitra dalam menyusun Laporan keuangan agar sesuai dengan format OJK (Gambar 3). Sebagai pelaku bisnis startup yang sebelumnya hanya melakukan pembukuan secara sederhana dan belum sesuai dengan format yang telah ditentukan OJK, maka perlu disiapkan dokumen agar penyusunan mudah dilakukan. Sesi pendampingan oleh tim abdimas dilaksanakan dengan rincian kegiatan sebagai berikut:

1. Tim abdimas menjelaskan akun-akun dalam Neraca yang ditunjukkan oleh Tabel 1 berikut ini (Rudianto, 2012); (Kasmir, 2017); Data diolah (2021):
Tabel 1. Akun-akun dalam Neraca

\begin{tabular}{|c|c|c|}
\hline & & Kelompok \\
\hline Aset & a. & $\begin{array}{l}\text { Aset lancar: adalah semua } \\
\text { harta perusahaan yang } \\
\text { diharapkan dapat berubah } \\
\text { menjadi uang dalam } \\
\text { tempo satu tahun } \\
\text { Contoh: Kas: uang tunai } \\
\text { dan setara kas, Rekening } \\
\text { pada bank (rekening giro } \\
\text { dan rekening tabungan), } \\
\text { Deposito berjangka, Surat } \\
\text { berharga, Piutang usaha } \\
\text { dan piutang wesel, } \\
\text { Persediaan: barang } \\
\text { dagangan atau bahan } \\
\text { baku, Biaya - biaya } \\
\text { dibayar dimuka: sewa, } \\
\text { asuransi, dan lain - lain, } \\
\text { Perlengkapan usaha, Aset } \\
\text { lancar lainnya }\end{array}$ \\
\hline & b. & $\begin{array}{l}\text { Aset tetap berwujud: } \\
\text { adalah semua asset yang } \\
\text { berumur lebih dari satu } \\
\text { tahun dan memiliki wujud } \\
\text { fisik } \\
\text { Contoh: Peralatan kantor, } \\
\text { Kendaraan, Mesin, Tanah, } \\
\text { Akumulasi penyusutan, } \\
\text { Aset tetap lainnya } \\
\text { Aset tetap tidak berwujud: } \\
\text { adalah semua aset yang } \\
\text { tidak memiliki wujud fisik } \\
\text { tetapi memiliki manfaat } \\
\text { nyata bagi perusahaan } \\
\text { Contoh: Goodwill, Hak } \\
\text { paten, Merek dagang, Hak } \\
\text { cipta }\end{array}$ \\
\hline & d. & $\begin{array}{l}\text { Aset lain - lain: adalah } \\
\text { aset yang tidak dapat } \\
\text { dikelompokkan pada } \\
\text { kelompok aset di atas. } \\
\text { Contoh: Titipan kepada } \\
\text { penjual, Bangunan dalam } \\
\text { pengerjaan, } \\
\text { jaminan, Uang muka } \\
\text { investasi }\end{array}$ \\
\hline Liabilitas & a. & $\begin{array}{l}\text { Utang lancar: adalah } \\
\text { kewajiban perusahaan } \\
\text { yang akan jatuh tempo } \\
\text { dalam waktu satu tahun. } \\
\text { Contoh: Utang usaha, } \\
\text { Utang wesel, Utang pajak, } \\
\text { Biaya yang masih harus } \\
\text { dbayar, Utang gaji, Utang } \\
\text { lancar lainnya }\end{array}$ \\
\hline & & $\begin{array}{l}\text { Pendapatan diterima } \\
\text { dimuka }\end{array}$ \\
\hline
\end{tabular}


Contoh: Sewa diterima dimuka, pendapatan diterima dimuka

c. Utang jangka Panjang: adalah kewajiban yang jatuh tempo lebih dari setahun

Contoh: Utang Bank jangka Panjang, Utang Obligas, Utang jangka Panjang lainnya

Ekuitas Ekuitas pemilik: semua kewajiban perusahaan kepada pemilik perusahaan

Contoh: Modal Saham, Laba

Ditahan, Agio Saham,

Cadangan Laba, Modal Sumbangan

Tabel 1 menjelaskan pengelompokkan aset, liabilitas dan ekuitas. Akun-akun aset disusun berdasarkan urutan likuiditasnya, yaitu seberapa cepat aset dapat dikonversi menjadi kas. Semakin mudah aset dikonversi menjadi kas, maka semakin didahulukan posisi pencatatannya dalam laporan posisi aset. Selain itu, aset juga dikelompokkan berdasarkan wujudnya, yaitu aset berwujud dan aset tidak berwujud. Akun-akun liabilitas disusun berdasarkan periode jatuh temponya. Liabilitas yang jatuh temponya dalam waktu satu tahun dikategorikan dalam utang lancar. Sedangkan liabilitas yang jatuh temponya lebih dari satu tahun dikategorikan dalam utang jangka panjang.

2. Tim abdimas menjelaskan akun-akun dalam Laporan Laba Rugi yang ditunjukkan dengan Tabel 2 berikut (Kasmir, 2017); (Rudianto, 2012); Data diolah (2021):

Tabel 2. Akun-akun dalam Laporan Laba Rugi

\begin{tabular}{|l|l|}
\hline \multicolumn{3}{|c|}{ Kelompok } \\
\hline Pendapatan & $\begin{array}{l}\text { Contoh: Pendapatan dari } \\
\text { penjualan, Pendapatan jasa, } \\
\text { Pendapatan lain-lain }\end{array}$ \\
\hline Coban & $\begin{array}{l}\text { Contoh: Harga Pokok } \\
\text { Penjualan, Beban } \\
\text { operasional, yang meliputi } \\
\text { beban administrasi dan } \\
\text { umum, beban penjualan, } \\
\text { beban sewa, Beban non } \\
\text { operasional seperti beban } \\
\text { bunga wesel, beban bunga } \\
\text { bank, beban bunga obligasi }\end{array}$ \\
\hline
\end{tabular}

Tabel 2 menjelaskan akun - akun dalam Laporan laba rugi dimana laporan ini memuat informasi mengenai pendapatan yang diterima dan biaya yang dikeluarkan pada periode tertentu. Kelompok pendapatan dapat berasal dari penjualan, jasa ataupun pendapatan yang berasal dari kegiatan non opersional. Biaya yang dilaporkan dalam laporan laba rugi adalah pengeluaran biaya yang berasal dari kegiatan operasional perusahaan, maupun yang berasal dari kegiatan non operasional.

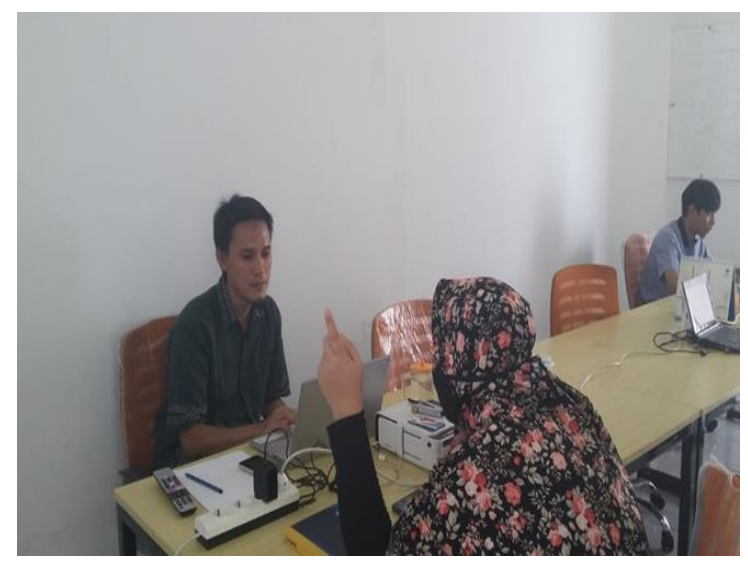

Gambar 3. Memberikan pendampingan dalam menyusun Laporan Keuangan

3) Tahap Bimbingan Pasca Pendampingan Tahap bimbingan dilakukan karena pendampingan penyusunan laporan keuangan, tanya-jawab dan evaluasi tidak cukup dilaksanakan selama satu hari, apalagi situasi dan kondisi yang tidak memungkinkan bagi tim untuk melakukan kunjungankunjungan selanjutnya kepada mitra karena saat itu masih dilanda wabah corona. Oleh sebab itu tim pun memberikan penawaran kepada mitra untuk melakukan bimbingan melalui whatsapp jika mitra ingin berkonsultasi. Mitra menyambut baik penawaran tim dengan menindaklanjuti secara kontinyu berkomunikasi dengan tim melalui whatsapp setelah pendampingan selesai.

\section{4) Tahap Evaluasi}

Setelah bimbingan dan konsultasi dilakukan, tim melakukan evaluasi terhadap mitra untuk mengetahui apakah ada perubahan dan dampak positif hasil abdimas yang telah dilakukan mulai dari pembekalan, pendampingan dan bimbingan dalam penyusunan pembuatan laporan keuangan sesuai format OJK. Tim melakukan wawancara terhadap mitra untuk mengevaluasi hasil abdimas. Adapun hasil wawancaranya adalah sebagai berikut :

1. Mitra memiliki pemahaman tentang alur pencatatan transaksi keuangan yang benar sesuai pospos atau akun-akun yang tepat.

2. Proses pencatatan transaksi harian keuangan menjadi lebih mudah, 
efisien dan efektif baik pencatatan bulanan, triwulanan dan tahunan

3. Mitra memiliki dasar pemahaman pembuatan laporan keuangan baik neraca dan laba rugi yang benar sesuai format yang diminta oleh OJK

4. Hasil laporan keuangan menjadi lebih rapi dan mudah dipahami

5. Mitra menjadi lebih mudah melakukan fungsi manajemen pengontrolan atas arus kas

6. Kinerja operasional dan penyerahan laporan keuangan kepada regulator dilakukan secara tepat waktu.

7. Mitra menjadi lebih mudah dalam pembuatan Rencana Kegiatan dan Anggaran Perusahaan (RKAP)

8. Mitra menjadi lebih mudah dalam memproyeksi rencana jangka menengah dan jangka panjang (menentukan titik break even usaha dan skala usaha perusahaan, valuasi dalam mengejar target usaha)

9. Mitra menjadi percaya diri dalam rangka mengajukan pendanaan kepada investor karena laporan keuangan usaha rintisan menjadi lebih mudah dipahami oleh investor.

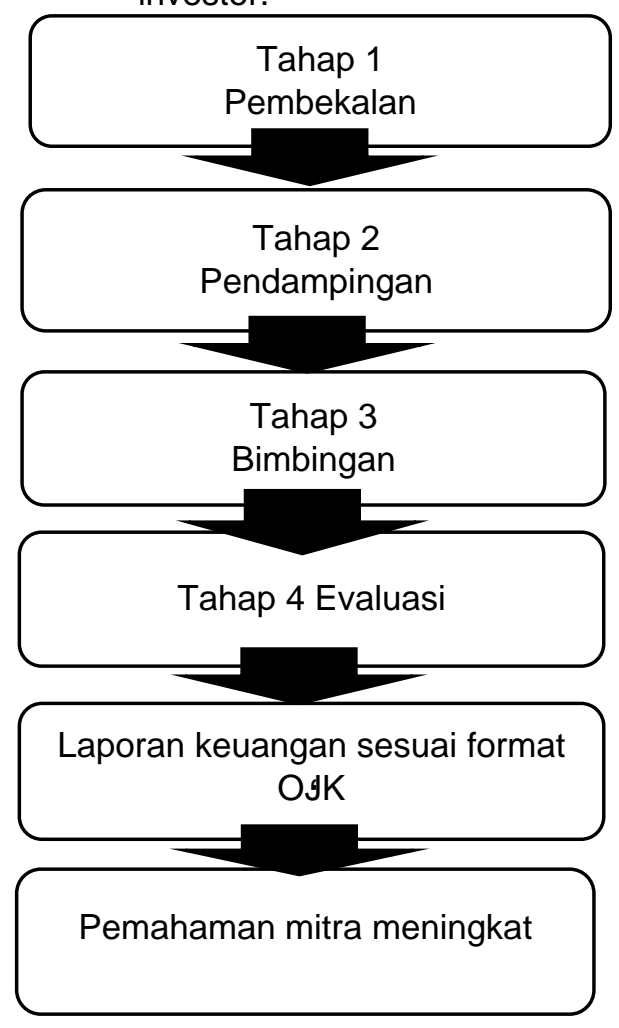

Gambar 4. Empat Tahap dan Hasil Akhir Abdimas
Kegiatan pengabdian masyarakat ini membuat kepatuhan mitra terhadap aturan regulator terjaga dengan baik karena setiap triwulanan, mitra harus melaporkan kegiatan operasionalnya dalam bentuk laporan keuangan triwulanan. Apabila pelaporan melewati jatuh tempo, regulator memberikan sanksi berupa denda dengan nominal tertentu per hari. Dengan pelaporan yang tepat waktu dan sesuai format yang diberikan mengindikasikan sikap kooperatif mitra dalam mematuhi aturan dan kebijakan regulator. Kepatuhan terhadap regulator dalam bentuk penyajian laporan keuangan yang benar merupakan bagian penting bagi usaha rintisan yang ingin tetap tumbuh dan berkembang.

Saat ini upaya menjalankan kepatuhan baru dijalankan secara manual dengan melakukan pelaporan triwulanan secara berkala, namun sebagai usaha rintisan di bidang inovasi keuangan digital yang sarat dengan teknologi maka untuk keberlanjutan bisnis ini, perlu mengembangkan sistem otomatisasi yang memanfaatkan Artificial Intellegence untuk membangun sistem tata kelola, pengawasan terhadap transaksi, kepatuhan dan pelaporan.. Perangkat tersebut adalah Regtech atau Regulatory Technology.

Teknologi regulasi (regtech) adalah cabang dari fintech yang berfokus pada peningkatan kepatuhan penyedia jasa keuangan dan sistem pengendalian internal. Antara lain, aplikasi regtech mengotomatiskan proses manajemen risiko, memfasilitasi pelaporan regulasi, mencegah penipuan, memungkinkan perusahaan untuk tetap mengikuti perubahan regulasi dan mendukung perencanaan strategis. (Petrasic, Saul, \& Bornfreund, 2017). Dengan pemahaman yang meningkat terhadap pelaporan keuangan yang benar berguna sebagai dasar bagi mitra untuk mengembangkan regtech pada tahap selanjutnya.

Penyajian laporan keuangan yang benar tidak hanya berguna untuk menjalin hubungan baik dengan regulator tetapi juga sangat penting untuk membuat kreditor atau investor tertarik dalam pendanaan. Kriteria apa saja yang membuat investor tertarik dan memutuskan untuk melakukan pendanaan pada usaha rintisan pemula bidang fintech dari sisi internal adalah (Hommel \& M. Bican, 2020) :1) Tim manajemen antara lain pengalaman tim di industri dan manajemen; kepribadian dan karakter founder dan timnya; jaringan sosial dan reputasi bisnis serta tim manajemen; jaringan sosial ini memegang peran utama dan penting bagi investor dalam memutuskan 
pendanaan, 2) Model dan rencana bisnis, rencana bisnis memperlihatkan wawasan yag mendalam dan membantu investor mengevaluasi perkiraan kinerja dan keterlibatan yang akan dibutuhkan 3) Produk yang ditawarkan, kriteria produk adalah keputusan utama investor tertarik. Selain itu yang dilihat dari produk juga status perkembangannya, teknologi di baliknya, dan perlindungan, di antara faktor-faktor lainnya dan 4) Keuangan, yang terpenting bagi investor adalah potensi pengembalian atau profit yang dapat diperkirakan, peluang likuiditas bagi investor dan potensi berbagi risiko terutama pada saat risiko tinggi, dimana bisnis yang dijalankan lebih mungkin untuk gagal tetapi akan menciptakan nilai yang relatif lebih banyak ketika berhasil, dan laporan keuangan divalidasi oleh badan yang terpercaya.

Memenuhi kriteria nomor 4 yaitu bagian keuangan, sangat penting bagi mitra dalam menyusun dan menyajikan laporan keuangan yang tepat sesuai aturan regulasi agar investor mudah memahaminya. Karena keberadaan dan pengelolaan mitra YukTakaful dalam menjalankan model bisnis insurtech tidak bisa lepas dari ruang lingkup ekosistem bisnis Inovasi Keuangan Digital (IKD) yang terdiri dari Otoritas, Pengawasan (OJK), Penyelenggara (Yuktakaful), Konsumen dan/atau pihak lain (Investor/Lembaga lain/Broker) yang memanfaakan platform digital secara bersamasama. Proses bisnis insurtech YukTakaful akan memiliki nilai tambah bagi pihak-pihak tersebut apabila dikelola dengan mengedepankan prinsip kehatian-hatian, transparan, akuntanbel, tidak merugikan satu sama lain dengan selalu menjunjung tinggi kepatuhan terhadap regulasi ptoritas yang berwenang.

\section{SIMPULAN DAN SARAN Simpulan}

Berdasarkan hasil bimbingan dan evaluasi yang telah dilakukan maka kegiatan abdimas pendampingan dalam penyusunan laporan keuangan pada usaha rintisan inovasi keuangan digital ini membawa manfaat yang sangat besar bagi mitra. Mitra mengalaami peningkatan tidak hanya dari segi pengetahuan dan pemahaman dalam penyusunan laporan keuangan saja tetapi juga muncul kepercayaan diri menghadapi regulator dan investor.

Pemahaman penyusunan laporan keuangan yang benar penting dan berguna sebagai dasar bagi mitra untuk mengembangkan perangkat regulatory technology (regtech) agar pelaporan keuangan dapat dikelola dan diawasi secara otomatisasi untuk mencegah unsur manipulasi internal perusahaan. Selain itu penyusunan laporan keuangan yang benar dan sesuai aturan regulator akan memudahkan investor memahaminya sehingga diharapkan mitra berpotensi memperoleh pendanaan untuk keberlangsungan usaha rintisan YukTakaful.

\section{Saran}

Tim abdimas menyarankan agar mitra meningkatkan infrastruktur pencatatan keuangan diantaranya menyediakan SDM yang mengelola transaksi keuangan. Perlunya peningkatan kapasitas SDM dengan mengikutsertakan dalam pelatihan. Tim abdimas menyarankan otomatisasi pencatatan keuangan mengingat usaha rintisan tersebut adalah usaha di bidang inovasi keuangan digital yang berpeluang untuk tumbuh dan berkembang.

\section{UCAPAN TERIMA KASIH}

Tim mengucapkan terima kasih kepada mitra YukTakaful yang telah berpartisipasi aktif selama kegiatan pendampingan dan LPPM Universitas Indraprasta PGRI karena telah menerbitkan surat tugas dalam kegiatan abdimas ini.

\section{DAFTAR RUJUKAN}

hanindo.co.id. (2020). Seberapa Jauh Peran Laporan Keuangan bagi Calon Investor? Retrieved 10 13, 2021, from www.hanindo.co.id:

https://hanindo.co.id/portofolio/seberap a-jauh-peran-lapran-keuangan-bagicalon-investor

Hommel, K., \& M. Bican, P. (2020). Digital Entrepreneurship in Finance: Fintechs and Funding Decision Criteria. Sustainability, https://doi.org/10.3390/su12198035.

Kasmir. (2017). Analisis Laporan Keuangan. Jakarta: Rajawali Pers.

kompas.com. (2020). Apa Itu Startup dan Perbedaanya dengan Perusahaan Konvensional? Retrieved 09 03, 2021, from www.kompas.com: https://money.kompas.com/read/2020/ 10/21/093719826/apa-itu-startup-danperbedaanya-dengan-perusahaankonvensional?page=all

liputan6.com. (2019). Pengertian Startup Adalah, Sejarah Singkat dan Karakteristiknya. Retrieved 0903 , 2021, from www.liputan6.com: https://www.liputan6.com/tekno/read/3 867489/pengertian-startup-adalahsejarah-singkat-dan-karakteristiknya

Njatrijani, R. (2019). Perkembangan Regulasi dan Pengawasan Financial Technology di Indonesia. Diponegoro Private Law 
Review, 4(No. 1), 462-473. Retrieved 10 13, 2021, from https://ejournal2.undip.ac.id/index.php/ dplr/article/download/5109/2717

paper.id. (2020). Klasik, Inilah Masalah Finansial yang Kerap Dialami Startup Indonesia. Retrieved 09 19, 2021, from www.paper.id:

https://www.google.com/amp/s/www.p aper.id/blog/finansial-umkm/masalahkeuangan-startup-indonesia/amp/

Petrasic, K., Saul, B., \& Bornfreund, M. (2017). The Emergence Al Regtech Solutions for AML and Sanctions Compliance. In Risk and Compliance Magazine. Birmingham, United Kingdom: Financial Worldwide Ltd.

republika.co.id. (2019). 64 Persen Start up Mengaku Kesulitan Susun Keuangan. Retrieved 09 19, 2021, from www.republika.co.id:

https://www.google.com/amp/s/m.repu blika.co.id/amp/ptcmtb396

Rivai, V., Basir, S., Sudarto, S., \& Veithzal, A. P. (2013). Commercial Bank Management: Manajemen Perbankan dari Teorike Praktik. Jakarta: Rajawali Pers.

Rudianto. (2012). Pengantar Akuntansi: Konsep dan Teknik Penyusunan Laporan Keuangan. Jakarta: Penerbit Erlangga.

Wahyuningsih, E. D., Setiawati, I., \& Prasojo, T. A. (2017). Pemberdayaan Pelaku Usaha Mikro dengan Memberikan Pelatihan Pembukuan Sederhana di Desa Bangunrejo Kecamatan Patebon Kabupaten Kendal. Implementasi Penelitian dan Pengabdian Masyarakat untuk Peningkatan Kekayaan Intelektual (pp. 491-495). Semarang: Universitas Muhammadiyah Smarang. 